\title{
Two new nematode species of the genus Tobrilus Andrássy, 1959 (Nematoda, Triplonchida) from Lake Baikal, Russia
}

\author{
Tatyana V. NAUMOVA ${ }^{1, *}$ \& Vladimir G. GAGARIN ${ }^{2}$ \\ ${ }^{1}$ Limnological Institute, Siberian Branch of the Russian Academy of Sciences, \\ Irkutsk, 664033, Russia. \\ ${ }^{2}$ Institute for Biology of Inland Waters, Russian Academy of Sciences, Borok, 152742, \\ Yaroslavl Province, Russia. \\ *Corresponding author: tvnaum@lin.irk.ru \\ ${ }^{2}$ Email: gagarin@ibiw.yaroslavl.ru \\ ${ }^{1}$ urn:1sid:zoobank.org:author:835C52CB-795C-48BF-B5A0-6DA2C303E060 \\ ${ }^{2}$ urn:1sid:zoobank.org:author:E28EA8D1-CBFE-4518-AA60-7F4388FBAD64
}

\begin{abstract}
Two new nematode species of the genus Tobrilus Andrássy, 1959 from Lake Baikal are described and illustrated. The first species Tobrilus elginus sp. nov. was found in the littoral zone of Maloye More Bays. The second species Tobrilus juliae sp. nov. dwells on bodies of dead sponges Lubomirskia baicalensis (Pallas, 1776). Tobrilus elginus sp. nov. is most similar to T. amabilis Tsalolikhin, 1974 and T. bekmanae Tsalolikhin, 1975. In contrast to the first species it has a shorter body and spicules, longer gubernaculum and a shorter supplements row. Its body is shorter and thinner, tail and supplement row are shorter and the vulva is more posterior as compared to the second species. The body size of Tobrilus juliae sp. nov. is most similar to T. securus Gagarin \& Naumova, 2011 and T. saprophagus Naumova \& Gagarin, 2017. From the first of these species it differs by the thinner body, shorter tail, comparatively shorter outer labial setae and shorter spicules. It differs from the second species by a thinner body, shorter male tail and shorter labial setae.
\end{abstract}

Keywords. Free-living nematodes, diversity, morphology, taxonomy.

Naumova T.V. \& Gagarin V.G. 2019. Two new nematode species of the genus Tobrilus Andrássy, 1959 (Nematoda, Triplonchida) from Lake Baikal, Russia. European Journal of Taxonomy 579: 1-13.

https://doi.org/10.5852/ejt.2019.579

\section{Introduction}

Lake Baikal is a fascinating freshwater reservoir known all over the Earth. Its shores and pure, crystal clean water attract numerous tourists as well as experts and researchers. The ancient age of the Lake (25-30 million years), the enormous depths of the water body (1637-1642 m) and its huge 7-8 km depression including sediment layers containing one fifth of the world's surface fresh water and its high oxygen saturation (up to $9.5 \mathrm{mg} / \mathrm{l}$ at the $1600 \mathrm{~m}$ depth point) make it a wonder of our planet. In 1996, UNESCO announced Lake Baikal a World's Heritage Object. 
Unique environments of the Lake inevitably provided favourable conditions for the formation of an abundant and diverse fauna including over 2600 species with a high level of endemism (more than 56\%) (Timoshkin 2001). The fauna of free-living nematodes comprises 114 species in 32 genera, 16 families and 8 orders according to the latest records (Naumova \& Gagarin 2019). These worms are encountered in rocky, sandy and silty substrates occupying all depths from the splash zone (above the water edge) to the abyssal zones. In terms of abunance, nematodes often dominate among other benthos groups.

The current world fauna records of Tobrilus Andrássy, 1959 include 22-24 valid species (Zullini 2006; Andrássy 2007), ten of which are present in Lake Baikal: T. amabilis Tsalolikhin, 1974, T. bekmanae Tsalolikhin, 1975, T. incognitus Tsalolikhin, 1972, T. latens Tsalolikhin, 1974, T. longisetosus Gagarin \& Naumova, 2011, T. macramphis Tsalolikhin, 1977, T. methanus Gagarin \& Naumova, 2016, T. saprophagus Naumova \& Gagarin, 2017, T. securus Gagarin \& Naumova, 2011, T. undophylus Shoshin, 1988 (Tsalolikhin 1974, 1975; Gagarin \& Naumova 2011, 2016; Naumova \& Gagarin 2017). A key for the identification of Tobrilus species from Lake Baikal based on male characters was published by Gagarin \& Naumova (2016).

The aim of this paper is to describe two new nematode species inhabiting Lake Baikal: T. elginus sp. nov. and T. juliae sp. nov.

\title{
Materials and methods
}

Nematodes were collected in the littoral zone of Lake Baikal from the following sites:

- Southern basin of Lake Baikal, near Cape Berezovy (51 $\left.30^{\prime} 11^{\prime \prime} \mathrm{N}, 104^{\circ} 32^{\prime} 33^{\prime \prime} \mathrm{E}\right), 5 \mathrm{~m}$ depth, bodies of dead sponges Lubomirskia baicalensis (Pallas, 1776) collected by divers on 6 September 2016.

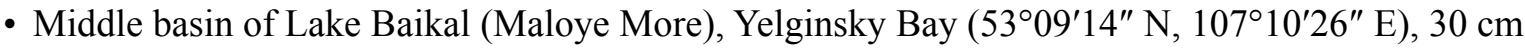
depth, sand, collected on 16 July 2018.

The samples contained numerous free-living nematodes, including both the species described herein. Nematodes were fixed by standard methods and mounted in glycerin on permanent slides. All observations were made using Olympus CX-21 and Nikon Eclipse 80i light microscopes with Nomarski DIC accessories. Images were taken using a Nikon DS-Fil digital camera and Intel Pentium Dual CPU E 2200 Processor Series for Desktop with the NIS-Elements D ver. 3.2 program for analysis and documentation of images from the preparations.

\section{Repositories}

HM RAS = Helminthological Museum, Center for Parasitology, Institute of Ecology and Evolution, Russian Academy of Science, Moscow, Russia

LIN-SB = Limnological Institute, Siberian Branch, Russian Academy of Sciences, Irkutsk, Russia.

\author{
Abbreviations \\ $a=$ body length / greatest body diameter \\ $b=$ body length / distance from anterior end to pharyngo-intestinal junction \\ $c=$ body length / tail length \\ $c^{\prime}=$ tail length / tail diameter at anus or cloaca \\ $\mathrm{L}=$ body length \\ $\mathrm{V}=$ distance from body anterior end to vulva expressed as percentage (\%) of the body length
}




\section{Results}

Phylum Nematoda Potts, 1932

Class Enoplea Inglis, 1983

Order Triplonchida Cobb, 1920

Family Tobrilidae de Coninck, 1965

Genus Tobrilus Andrássy, 1959

\section{Type species}

Tobrilus gracilis $($ Bastian, 1865) = Trilobus gracilis Bastian, 1865.

Diagnosis (after Andrássy 2007; Holovachov \& Shoshin 2014)

Body 1.0-4.5 $\mu \mathrm{m}$ long. Cuticle smooth or very finely annulated. Buccal cavity cup-or funnel-shaped, with overlapping subventral pocket and teeth close to each other. Vagina moderately strong. Spicules comparatively short. Supplements 3 to 13 , mostly six, small, non-echinate, but with a small central thorn, submerged, not protruding. Spacing between supplements nearly equal.

Tobrilus elginus sp. nov. urn:1sid:zoobank.org:act:0248B1A1-53A2-4EFD-97E4-E8AD0F6D030C

Figs 1-2, Table 1 (morphometric)

\section{Diagnosis}

Tobrilus elginus sp. nov. is characterized by a 2200-2995 $\mu \mathrm{m}$ long body; cuticle smooth under light microscope; crystalloids absent; inner labial sensillae papilliform; six outer labial sensillae in the shape of smooth non-articulated setae $14-17 \mu \mathrm{m}$ long, $45-57 \%$ for males and $44-59 \%$ for females of labial region width; four cephalic sensillae on the shape of thin and smooth setae 6-8 $\mu \mathrm{m}$ long; buccal cavity spacious, funnel-shaped; dorsal pocket and its tooth absent; both subventral pockets overlapping adjacent to each other. Spicules comparatively thick, slightly curved, short, 50-53 $\mu \mathrm{m}$ long, 1.1-1.3 long as the cloacal body diameter; gubernaculum in the shape of 'gutter'; precloacal supplements 6 in number, small, submerged; tail slender, long, elongate-conical, with terminal seta.

\section{Type material}

\section{Holotype}

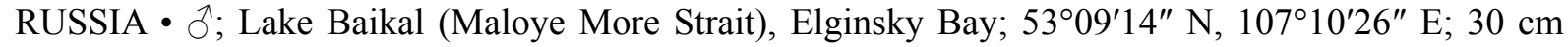
depth; 16 Jul. 2018; sand; HM RAS slide reference number 102/69.

\section{Paratypes}

RUSSIA $\bullet 2 \hat{\jmath} \widehat{\partial}, 1$; same collection data as for holotype; HM RAS slide reference number 102/69

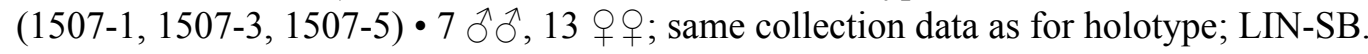

\section{Etymology}

The specific epithet means 'from Elga', the type locality name.

\section{Description}

\section{Male}

Body comparatively long and thin. Cuticle smooth under light microscope, 1.5-2.0 $\mu \mathrm{m}$ thick. Body diameter at the posterior pharynx end 1.7-2.0 times the width of the labial region. Crystalloids absent. Somatic setae rare and short, 5-7 $\mu \mathrm{m}$ long. Labial region slightly offset from the adjacent body; lips 


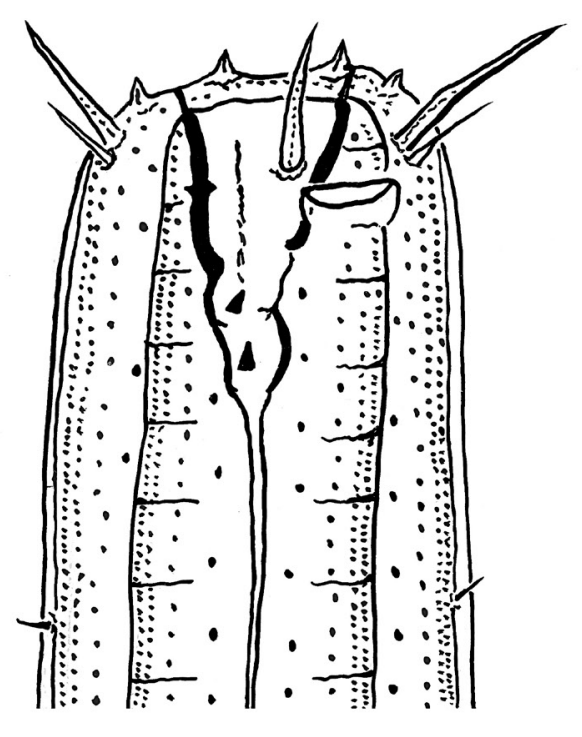

A

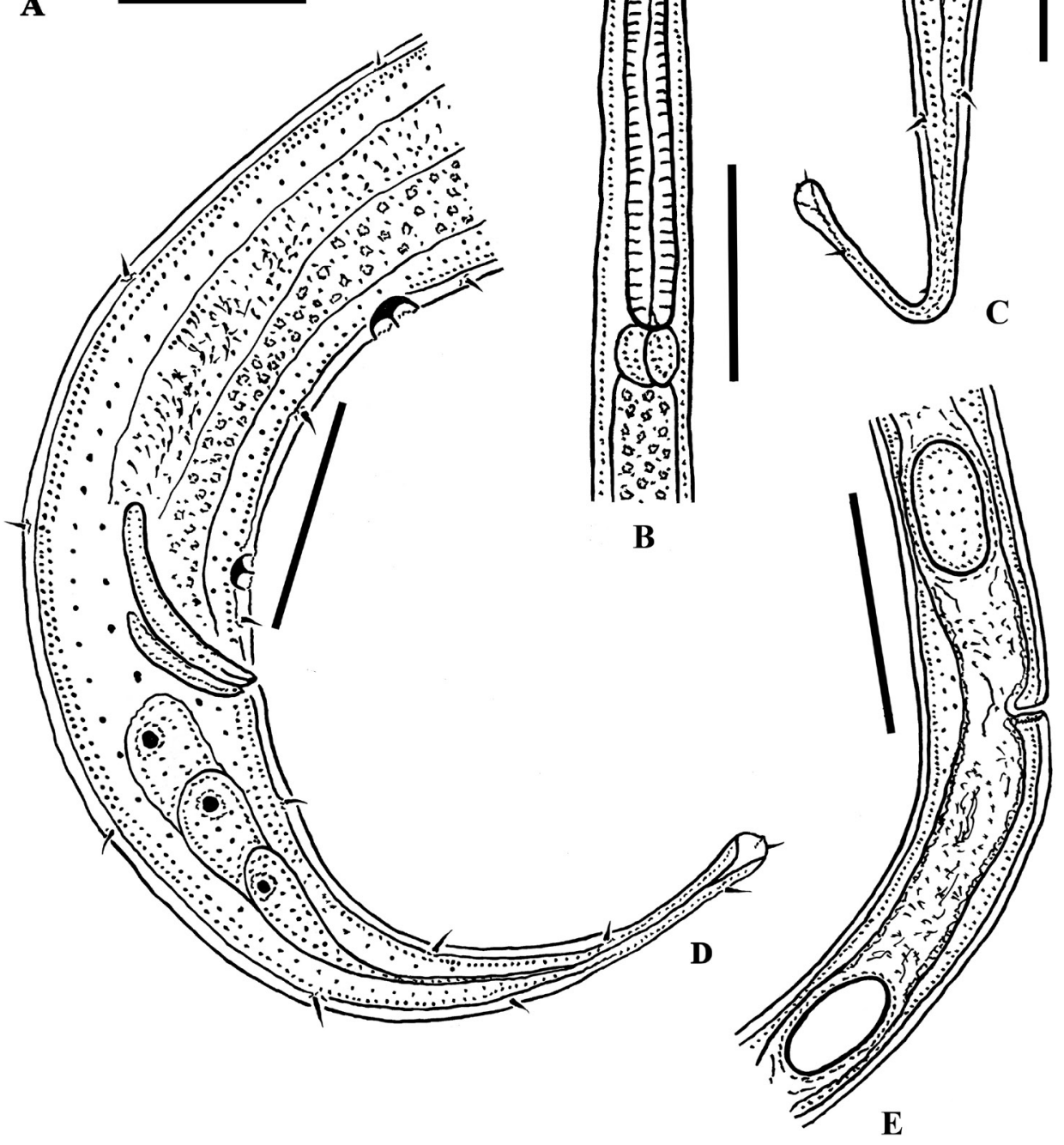

Fig. 1. Tobrilus elginus sp. nov. A. Male anterior end. B. Male pharyngeal region. C. Female posterior body end. D. Male posterior body end. E. Female vulva region. Scale bars: A $=20 \mu \mathrm{m} ; \mathrm{B}, \mathrm{E}=100 \mu \mathrm{m}$; $\mathrm{C}-\mathrm{D}=50 \mu \mathrm{m}$. 

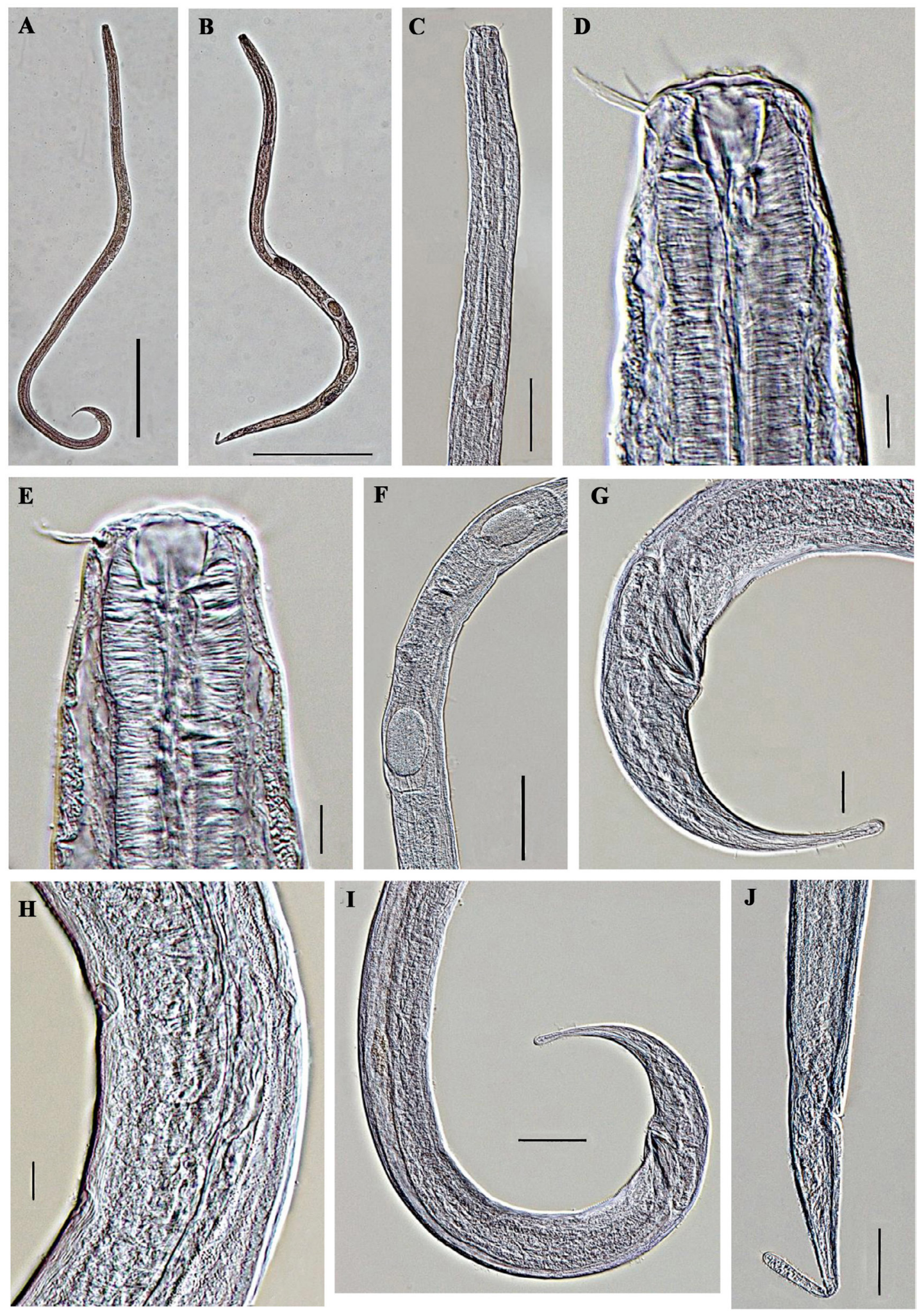

Fig. 2. Tobrilus elginus sp. nov., light micrographs. A. Entire male. B. Entire female. C. Male pharyngeal region. D. Male anterior end. E. Female anterior end. F. Female vulva region. G, I. Male posterior body end. H. Male supplement region. J. Female posterior body end. Scale bars: A-B $=500 \mu \mathrm{m} ; \mathrm{C}, \mathrm{F}=$ $100 \mu \mathrm{m} ; \mathrm{D}-\mathrm{E}, \mathrm{H}=10 \mu \mathrm{m} ; \mathrm{G}=20 \mu \mathrm{m} ; \mathrm{I}-\mathrm{J}=50 \mu \mathrm{m}$. 
Table 1. Measurements (in $\mu \mathrm{m}$ ) of Tobrilus elginus sp. nov., presented as mean and range.

\begin{tabular}{|c|c|c|c|}
\hline Character & Holotype $\lesssim$ & $\lesssim \sigma^{\lambda}$ & 우우 \\
\hline Number of specimens & 1 & 10 & 14 \\
\hline Body length (L) & 2648 & $2551(2235-2845)$ & $2410(2200-2995)$ \\
\hline$a$ & 47 & $46(39-56)$ & $42(37-46)$ \\
\hline$b$ & 5.4 & $5.2(4.8-5.6)$ & $4.7(4.5-4.9)$ \\
\hline$c$ & 15.6 & $15.8(14.2-18.7)$ & $12.5(11.0-13.4)$ \\
\hline$c^{\prime}$ & 3.9 & $3.8(3.3-4.4)$ & $6.0(5.0-6.9)$ \\
\hline $\mathrm{V}, \%$ & - & - & $61(57-64)$ \\
\hline Labial region diameter & 28 & $28(27-30)$ & $30(27-32)$ \\
\hline Body diameter & 57 & $56(45-65)$ & $58(53-65)$ \\
\hline Anal or cloacal diameter & 44 & $43(40-47)$ & $32(30-40)$ \\
\hline Stoma (buccal cavity) length & 33 & $31(28-33)$ & $32(28-37)$ \\
\hline Outer labial setae length & 15 & $15(14-17)$ & $15(14-17)$ \\
\hline Cephalic setae length & 8 & $7(6-8)$ & $7(5-8)$ \\
\hline Nerve ring from anterior body end & 130 & $127(110-135)$ & $132(120-150)$ \\
\hline Pharynx length & 490 & $487(440-525)$ & $505(475-532)$ \\
\hline Posterior pharynx end to vulva & - & - & $956(792-1180)$ \\
\hline Posterior pharynx end to cloaca & 1988 & $1903(1638-2188)$ & - \\
\hline Vulva to anus & - & - & $757(660-1090)$ \\
\hline Tail length & 170 & $162(150-175)$ & $193(170-228)$ \\
\hline Spicules length & 52 & $51(50-53)$ & - \\
\hline Gubernaculum length & 23 & $24(20-26)$ & - \\
\hline Number of supplements & 6 & 6 & - \\
\hline
\end{tabular}

well developed. Six inner labial sensillae papilliform. Six outer labial sensillae in the shape of smooth, non-articulated setae $14-17 \mu \mathrm{m}$ long, $45-57 \%$ of labial region width. Four cephalic sensillae in the shape of thin and smooth setae, $6-8 \mu \mathrm{m}$ long. Both circles of setae drawn close together. Cheilostom of the average size. Buccal cavity spacious, funnel-shaped, with thick walls. Dorsal pocket and its tooth absent. Both subventral pockets overlapping adjacent to each other. Its teeth small, close to each other ( $\sim \mu \mathrm{m}$ away). Stoma 1.1-1.3 times as long as labial region width. Amphidial fovea cup-shaped, opening at the level of buccal cavity. Pharynx muscular, comparatively long, expanding gradually along entire length. Cardiac glands large, rounded, $20-23 \mu \mathrm{m}$ in diameter. Ventral gland, its canal, ampulla and excretory pore not seen. 
Testes paired, opposed, situated to the left of intestine; anterior testes outstretched, posterior testis reflexed. Vas deferens well developed. Spicules thick, slightly curved, short, 1.1-1.3 times as long as the cloacal body diameter, apically bifurcate. Gubernaculum in the shape of 'gutter', $42-53 \%$ of the spicule length. Precloacal supplements 6 in number, small, submerged. Supplement ampulla flattened, contents concentrated at ampulla base. Supplement cap absent. Central thorn protruding slightly above cuticle. Supplements approximately identical in size and situated about equidistant from each other. The closest to cloaca supplement at 21-30 $\mu \mathrm{m}$ away from it; supplement row 355-435 $\mu \mathrm{m}$ long. Tail slender, elongate-conical, with terminal seta 6-8 $\mu \mathrm{m}$ long. Caudal glands well developed; spinneret in the shape of a short, conical tube.

\section{Female}

General morphology similar to that of males in structure of cuticle and anterior body end. Cardia small, surrounded by three round glands. Prerectum not observed. Rectum length equal to or slightly greater than anal body diameter. Reproductive system didelphic, amphidelphic. Ovaries situated to the left of intestine, reflexed and comparatively short. Oocytes numerous. Vulva a transverse slit and situated slightly posterior to mid-body. Vulval lips not sclerotized and not protruding outside the body contour. Cuticular wrinkles around vulva and vulva glands not seen. Vagina short, with thick walls. Uterus containing numerous spermatozoa and 1-2 eggs, measuring 65-105 $\times 26-50 \mu \mathrm{m}$. Tail slender, long, elongate-conical, with terminal seta. Caudal glands well developed.

\section{Remarks}

Tobrilus elginus sp. nov. is most similar to T. amabilis and T. bekmanae. The new species differs from the first species in the shorter body $(\hat{\partial} \mathrm{L}=2.2-2.8 \mathrm{~mm}$, + $\mathrm{L}=2.2-2.9 \mathrm{~mm}$ vs $\widehat{\overbrace{}} \mathrm{L}=2.8-3.0 \mathrm{~mm}$, ㅇ $\mathrm{L}=3.0-3.1 \mathrm{~mm}$ in T. amabilis), shorter spicules (50-53 $\mu \mathrm{m}$ long vs 55-58 $\mu \mathrm{m}$ long in T. amabilis), longer gubernaculum (20-26 $\mu \mathrm{m}$ long vs 16-17 $\mu \mathrm{m}$ long in T. amabilis), shorter supplement row (355$435 \mu \mathrm{m}$ long vs $487 \mu \mathrm{m}$ long in T. amabilis) (Tsalolikhin 1974). Tobrilus elginus sp. nov. differs from

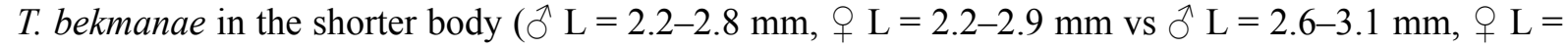

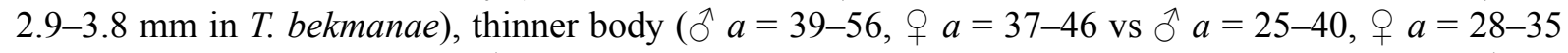
in T. bekmanae), shorter tail ( $\delta^{\prime} c=14.2-18.7, c^{\prime}=3.3-4.4$, ㅇ $c=11.0-13.4, c^{\prime}=5.0-6.9$ vs ${ }^{\lambda} c=$ 8.5-13.7, $c^{\prime}=6$, ㅇ $c=7.4-10.0, c^{\prime}=9$ in $T$. bekmanae), a more posterior vulva ( $\mathrm{V}=57-64 \% \mathrm{vs} \mathrm{V}=$ $41-50 \%$ in T. bekmanae), shorter supplement row (355-435 $\mu \mathrm{m}$ long vs $334 \mu \mathrm{m}$ long in T. bekmanae) (Tsalolikhin 1975).

Tobrilus juliae sp. nov. urn:1sid:zoobank.org:act:34D3DBF2-8273-410C-8CA0-CAC1279ACA77

Figs 3-4, Table 2 (morphometric)

\section{Diagnosis}

Tobrilus juliae sp. nov. is characterized by a 1800-2386 $\mu \mathrm{m}$ long body; cuticle smooth under light microscope; crystalloids absent; inner labial sensillae papilliform; six outer labial sensillae in the shape of smooth, non-articulated setae 4-6 $\mu \mathrm{m}$ long for males (24-35\% of labial region width) and 5-6 $\mu \mathrm{m}$ long for females (28-38\% of labial region width); four cephalic sensillae on the shape of thin and smooth setae 3-4 $\mu \mathrm{m}$ long for males and 2-4 $\mu \mathrm{m}$ long for females; buccal cavity spacious, barrelshaped; dorsal pocket and it tooth absent; both subventral pockets overlapping adjacent to each other. Spicules slightly curved, $45-50 \mu \mathrm{m}$ long, $1.2-1.5$ long as the cloacal body diameter; gubernaculum in the shape of 'gutter'; precloacal supplements 6-7 in number, small, submerged; tail short, elongateconical, with terminal seta. 


\section{Type material}

Holotype

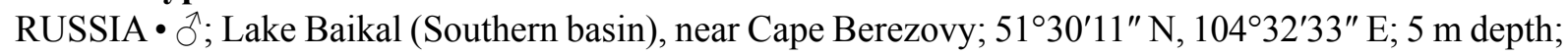
6 Sep. 2016; bodies of dead sponges Lubomirskia baicalensis collected by divers; HM RAS slide reference number 102/70.

\section{Paratypes}

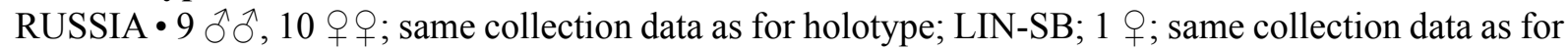
holotype; HM RAS slide reference number 102/70 (1390-1).

\section{Etymology}

The species named in gratitude to Ms Julia Zvereva.

\section{Description}

\section{Male}

Body comparatively long and thin. Cuticle smooth under light microscope, 1.0-1.5 $\mu \mathrm{m}$ thick. Body diameter at the posterior pharynx end 2.1-2.5 times the width of the labial region. Crystalloids absent. Somatic setae rare and short, 3-4 $\mu \mathrm{m}$ long. Labial region only slightly offset from the adjacent body; lips well developed. Six inner labial sensillae papilliform. Six outer labial sensillae in the shape of smooth, non-articulated setae 4-6 $\mu \mathrm{m}$ long, 24-35\% of labial region width. Four cephalic sensillae in the shape of thin and smooth setae 3-4 $\mu \mathrm{m}$ long. Both circles of setae drawn close together. Cheilostoma of the average size. Buccal cavity spacious, barrel-shaped, with thick walls. Dorsal pocket and it tooth absent. Both subventral pockets overlapping adjacent to each other. Its teeth small, close to each other (distance $\sim 3 \mu \mathrm{m}$ ). Stoma 1.0-1.2 as long as labial region width. Amphidial fovea cup-shaped, opening at the level of buccal cavity. Pharynx muscular, comparatively long, expending gradually along entire length. Cardiac glands large, rounded, $15-17 \mu \mathrm{m}$ in diameter. Ventral gland, its canal, ampulla and excretory pore not seen.

Testes paired, opposed, situated to the left of intestine; anterior testis outstretched, posterior testis reflexed. Vas deferens well developed. Spicules slightly curved, comparatively short, 1.2-1.5 times as long as the cloacal body diameter, apically bifurcate. Gubernaculum in the shape of 'gutter', $43-47 \%$ of the spicule length. Precloacal supplements 6-7 in number, small, submerged. Supplement ampulla flattened, its contents concentrated at ampulla base. Supplement cap absent. Central thorn protruding slightly above cuticle. Supplements approximately identical in size and situated about equidistant from each other. The closest to cloaca supplement at 11-20 $\mu \mathrm{m}$ away from it; supplement row 175-290 $\mu \mathrm{m}$ long. Tail short, elongate-conical, with terminal seta 3-5 $\mu \mathrm{m}$ long. Caudal glands well developed; spinneret in the shape of a short, conical tube.

\section{Female}

General morphology similar to that of males in structure of cuticle and anterior body end. Six outer labial sensillae in the shape of smooth setae 5-6 $\mu \mathrm{m}$ long, 28-38\% of labial region width; four cephalic sensillae in the shape of thin, smooth setae 2-4 $\mu \mathrm{m}$ long. Cardia small, surrounded by three round glands. Rectum length equal to or slightly greater than anal body diameter. Reproductive system didelphic, amphidelphic. Ovaries situated to the left of intestine, reflexed and comparatively short. Oocytes numerous. Vulva a transverse slit and situated slightly posterior to mid-body. Vulval lips not sclerotized and not protruding outside the body contour. Cuticular wrinkles around vulva and vulva glands not observed. Vagina short. Uterus containing numerous spermatozoa and 1-2 eggs, measuring 70-72 $\times 40-43 \mu \mathrm{m}$. Tail short, elongate-conical, with subterminal seta. Caudal glands well developed. 


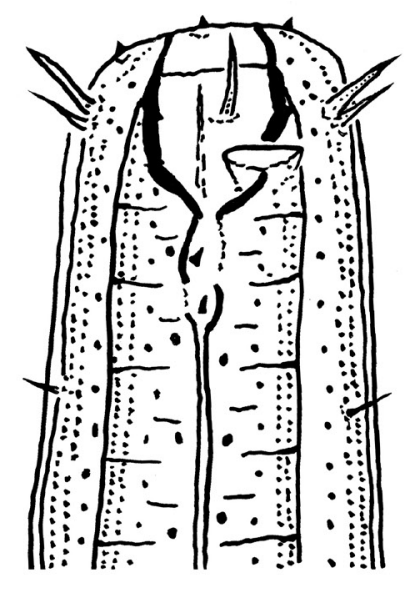

A
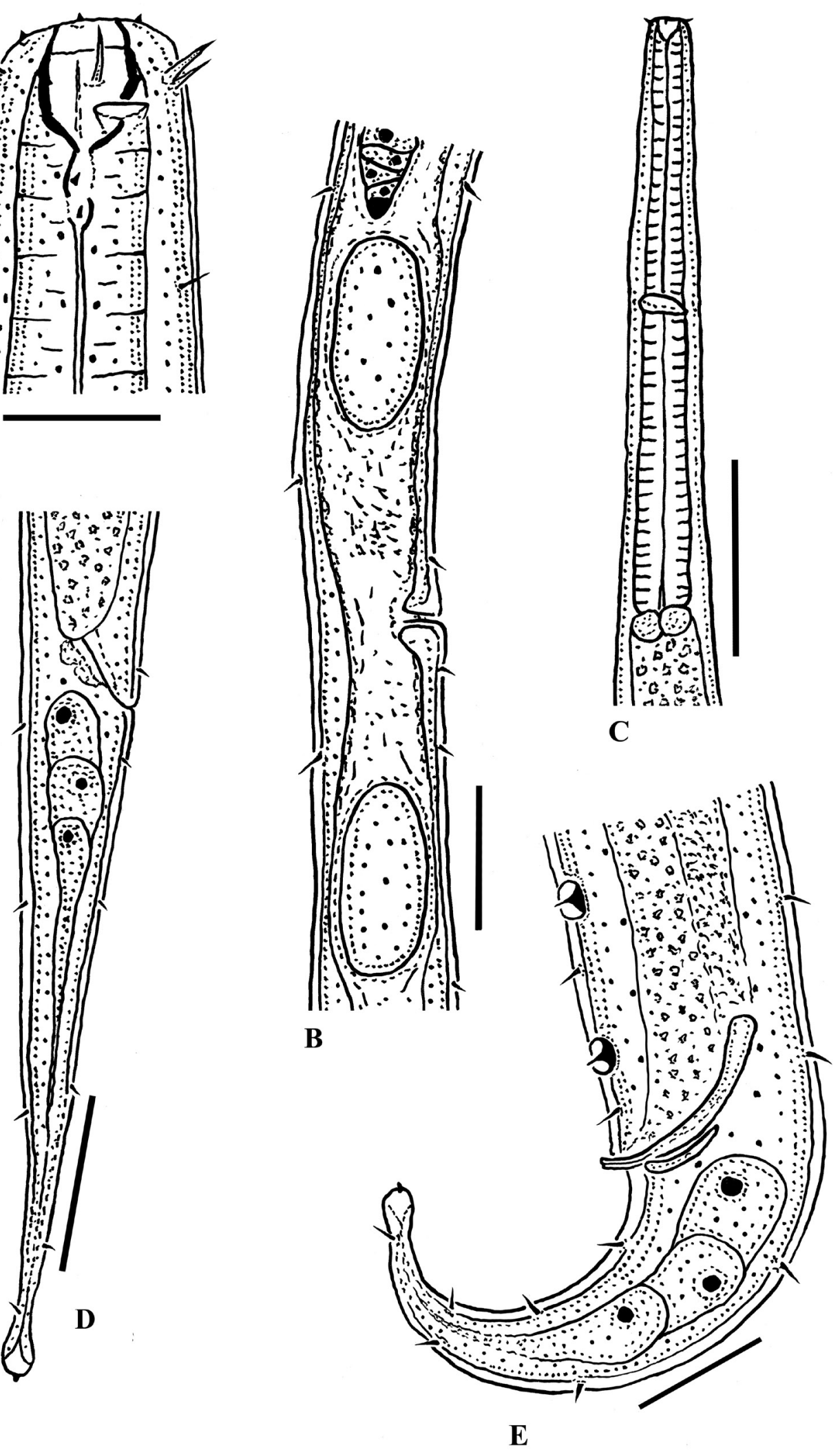

Fig. 3. Tobrilus juliae sp. nov. A. Male anterior end. B. Female vulva region. C. Male pharyngeal region. D. Female posterior body end. E. Male posterior body end. Scale bars: $A=15 \mu \mathrm{m} ; \mathrm{B}=50 \mu \mathrm{m} ; \mathrm{C}=$ $100 \mu \mathrm{m} ; \mathrm{D}=40 \mu \mathrm{m} ; \mathrm{E}=30 \mu \mathrm{m}$. 


\section{Remarks}

Tobrilus juliae sp. nov. is most similar to T. securus and T. saprophagus in body size. From the first species it differs in the thinner body ( $a=41-63$ vs $a=25-40$ in $T$. securus), shorter tail ( $c=11.3-$ $23.4, c^{\prime}=2.4-6.1$ vs $c=6.7-8.4, c^{\prime}=6.3-9.3$ in $T$. securus , comparatively shorter outer labial setae (24-35\% of labial region width vs $40-45 \%$ of labial region width in T. securus) and shorter spicules (45-50 $\mu \mathrm{m}$ long vs 52-58 $\mu \mathrm{m}$ long in T. securus) (Gagarin \& Naumova 2011). From the second species $T$. juliae sp. nov. differs in the thinner body ( $a=41-63$ vs $a=30-43$ in $T$. saprophagus), shorter tail in males $(\hat{\partial} c=17.5-23.4$ vs $\widehat{\partial} c=11.5-16.7$ in T. saprophagus) and shorter outer labial setae $(4-7 \mu \mathrm{m}$ long, 24-35\% labial region width vs 10-12 $\mu \mathrm{m}$ long, 37-46\% of labial region width in $T$. saprophagus (Naumova \& Gagarin 2017).
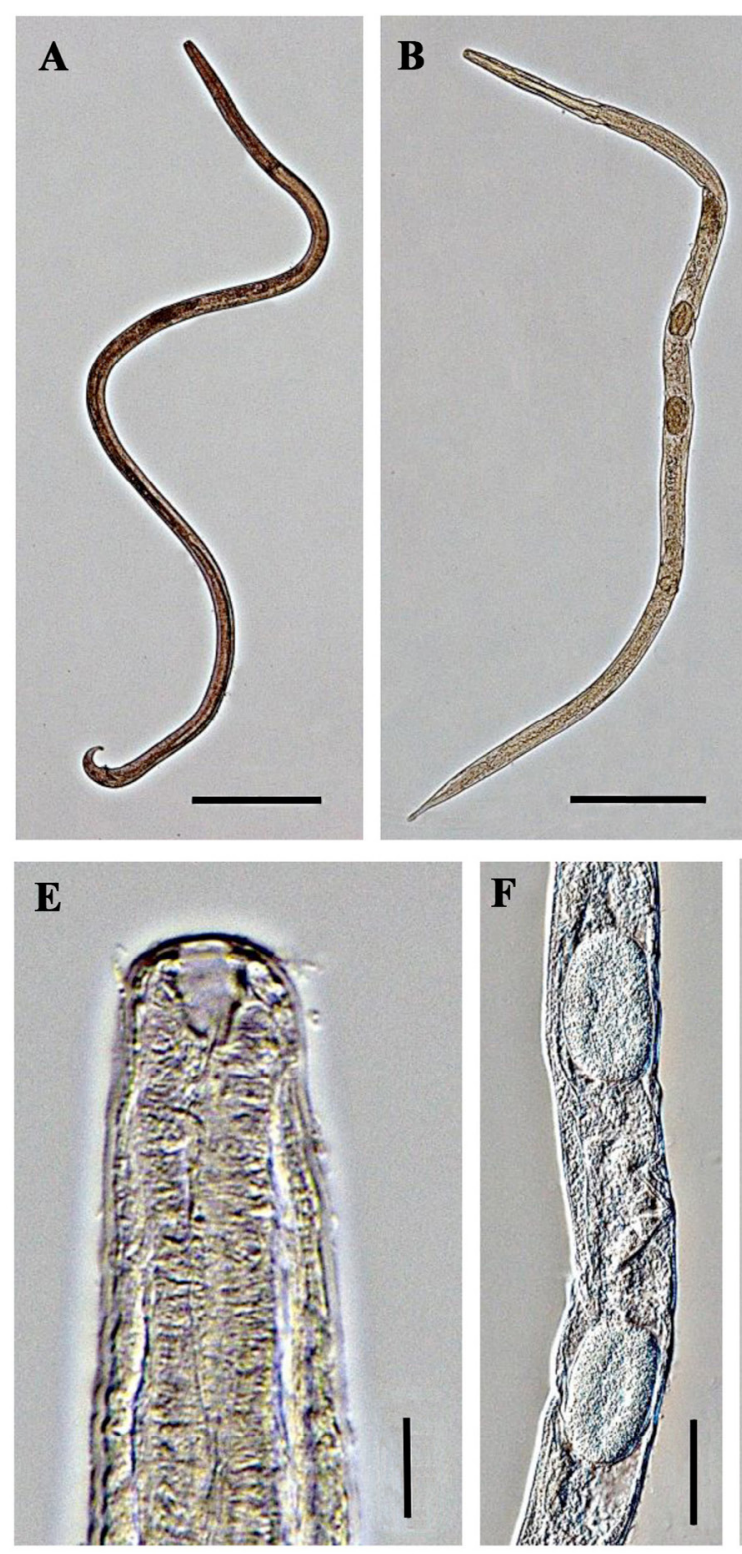
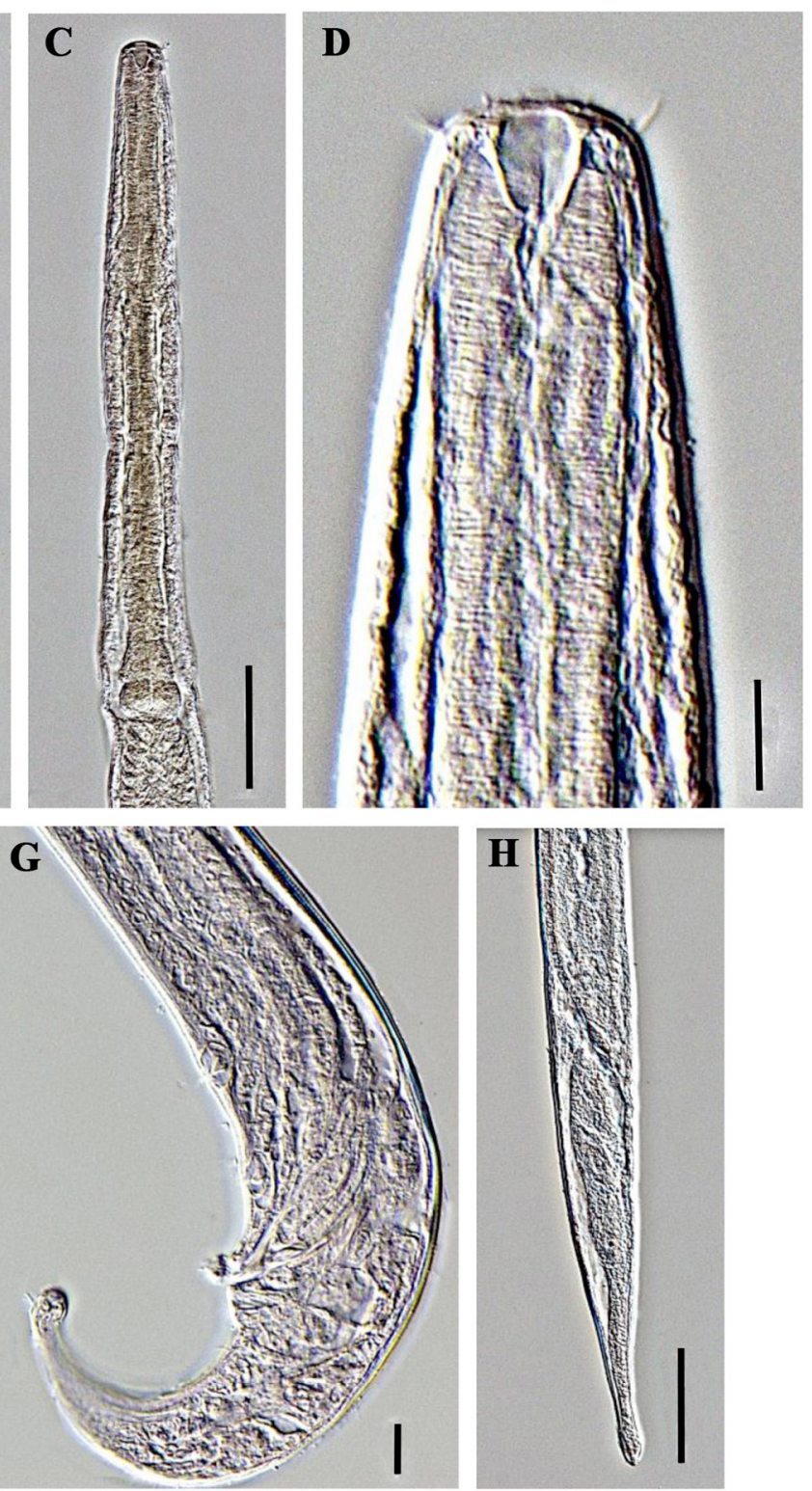

Fig. 4. Tobrilus juliae sp. nov., light micrographs. A. Entire male. B. Entire female. C. Male pharyngeal region. D. Female anterior end. E. Male anterior end. F. Female vulva region. G. Male posterior body end. H. Female posterior body end. Scale bars: A-B $=250 \mu \mathrm{m}$; C, F, H $=50 \mu \mathrm{m}$; D-E, G $=10 \mu \mathrm{m}$. 
Table 2. Measurements (in $\mu \mathrm{m}$ ) of Tobrilus juliae sp. nov., presented as mean and range.

\begin{tabular}{|c|c|c|c|}
\hline Character & Holotype ${ }^{\lambda}$ & $\hat{\partial} \sigma^{\lambda}$ & 우우 \\
\hline Number of specimens & 1 & 10 & 11 \\
\hline Body length (L) & 2067 & $2121(1891-2386)$ & $2038(1800-2298)$ \\
\hline$a$ & 52 & $53(43-63)$ & $51(41-58)$ \\
\hline$b$ & 6.8 & $6.8(6.4-7.3)$ & $6.7(6.3-7.3)$ \\
\hline$c$ & 20.7 & $20.8(17.5-23.4)$ & $12.9(11.3-14.2)$ \\
\hline$c^{\prime}$ & 2.6 & $2.7(2.4-3.6)$ & $5.3(4.6-6.1)$ \\
\hline $\mathrm{V}, \%$ & - & - & $44(43-47)$ \\
\hline Labial region diameter & 17 & $17(15-19)$ & $17(15-18)$ \\
\hline Body diameter & 40 & $40(33-45)$ & $41(35-48)$ \\
\hline Anal or cloacal diameter & 38 & $38(30-40)$ & $30(28-35)$ \\
\hline Stoma (buccal cavity) length & 20 & $19(18-20)$ & $19(18-22)$ \\
\hline Outer labial setae length & 6 & $5(4-6)$ & $6(5-7)$ \\
\hline Cephalic setae length & 4 & $4(3-4)$ & $3(2-4)$ \\
\hline Nerve ring from anterior body end & 105 & $103(100-121)$ & $117(110-132)$ \\
\hline Pharynx length & 305 & $313(290-342)$ & $304(275-338)$ \\
\hline Posterior pharynx end to vulva & - & - & $594(530-645)$ \\
\hline Posterior pharynx end to cloaca & 1662 & $1705(1488-1943)$ & - \\
\hline Vulva to anus & - & - & $981(825-1180)$ \\
\hline Tail length & 100 & $102(90-115)$ & $158(140-170)$ \\
\hline Spicules length & 47 & $48(45-50)$ & - \\
\hline Gubernaculum length & 23 & $22(20-23)$ & - \\
\hline Number of supplements & 7 & $6-7$ & - \\
\hline
\end{tabular}

\section{Discussion}

Tobrilus is considered the most primitive genus within the family Tobrilidae; the small and simple supplements in variable (non-constant) number seem to support this opinion (Andrássy 2007). The genus is distributed in Europe, Asia, Africa, both Americas and Australia (Andrássy 2007). Half of the species in the genus Tobrilus (12 of 22-24 valid species) are inhabitants of Lake Baikal where they are encountered in the depth range of 0 to $1520 \mathrm{~m}$, as well as in the splash zone $(0.5 \mathrm{~m}$ above the water edge). Most of the species are endemic and only two have been found elsewhere in water bodies of the Baikal region (Gagarin 1993; Naumova et al. 2010). Evidently, Lake Baikal is the epicenter of Tobrilus speciation. 
The genus Tobrilus is considered a basic form for the whole Tobrilidae family. According to Hodda (2011), the world tobrilid fauna includes 162 species in 10 genera. At present, Baikal is the home of 43 species of the Tobrilidae family, i.e., $1 / 4$ of the world fauna (Naumova \& Gagarin 2019).

The authors believe that the knowledge on the species diversity of Baikal representatives of the genus is far from complete and that new exciting contributions are to be expected. Use of molecular-genetic approaches would enable the researchers to highlight the phylogeny of this group and estimate the evolution rate within the genus. These are the objectives of future investigations.

\section{Acknowledgements}

This work was supported by framework of the Russian State Project tasks No. AAAA-A16-116122110067-8, No. AAAA-A16-116122110064-7 and No. AAAA-A15-118012690105-0. The authors are grateful Dr Vladimir A. Gusakov (Institute for Biology of Inland Waters Russian Academy of Sciences) for assistance with preparing microphotographs. Thanks to Julia M. Zvereva (Limnological Institute Siberian Branch Russian Academy of Sciences) for collection of material. We offer sincere thanks to the anonymous reviewers and editor Dr Rudy Jocqué for their valuable comments and remarks. The English version was partially revised and translated by Elena M. Timoshkina.

\section{References}

Andrássy I. 2007. Free-living Nematodes of Hungary (Nematoda Errantia). II. Hungarian Natural History Museum and Systematic Zoology Research Group of the Hungarian Academy of Sciences. Budapest.

Gagarin V.G. 1993. Free-living Nematodes of Freshwater in Russia and Adjacent Countries (Orders Monhysterida, Araeolaimida, Chromadorida, Enoplida, Mononchida). St.-Petersburg, Gidrometeoizdat. [In Russian].

Gagarin V.G. \& Naumova T.V. 2011. Two species of free-living nematodes from Lake Baikal. Inland Water Biology 4 (3): 273-278. https://doi.org/10.1134/S1995082911030072

Gagarin V.G. \& Naumova T.V. 2016. Tobrilus methanus sp. n. and Tripyla posolskii sp. n. (Nematoda, Triplonchida) from Lake Baikal, Russia. Zootaxa 4196 (1): 95-106.

https://doi.org/10.11646/zootaxa.4196.1.5

Hodda M. 2011. Phylum Nematoda Cobb 1932. In: Zhang Z.-Q. (ed.) Animal Biodiversity: An Outline of Higher-Level Classification and Survey of Taxonomic Richness. Zootaxa 3148 (1): 63-96.

https://doi.org/10.11646/zootaxa.3148.1.11

Holovachov O. \& Shoshin A. 2014. Order Triplonchida Cobb, 1919. In: Schmidt-Rhaesa A. (ed.) Handbook of Zoology. Gastrotricha, Cycloneuralia and Gnathifera. V. 2. Nematoda: 251-276. Berlin, Boston. De Gruyter.

Naumova T.V. \& Gagarin V.G. 2017. Tobrilus saprophagus sp. n. and Epitobrilus interstitialis sp. n. (Nematoda, Triplonchida) from Lake Baikal, Russia. Zootaxa 4353 (1): 133-145.

https://doi.org/10.11646/zootaxa.4353.1.8

Naumova T.V. \& Gagarin V.G. 2019. Review of the free-living Nematode (Nematoda) fauna of Lake Baikal. Zootaxa 4608 (1): 101-118. https://doi.org/10.11646/zootaxa.4608.1.5

Naumova T.V., Gagarin V.G. \& Timoshkin O.A. 2010. First data on the fauna of free-living nematodes (Nematoda) in the waters of North Irkutsk Region. In: Index of Animal Species Inhabiting Lake Baikal and its Catchment Area. Vol. II, Basin and Channels in the South of East Siberia and North Mongolia, Book 2: 1009-1024. Novosibirsk, Nauka. [In Russian]. 
Timoshkin O.A. 2001. Lake Baikal: diversity of fauna, problems of its immiscibility and origin, ecology and "exotic" communities. In: Index of Animal Species Inhabiting Lake Baikal and its Catchment Area. Vol. 1, Lake Baikal, Book 1: 17-74. Novosibirsk, Nauka. [In Russian].

Tsalolikhin S.Ya. 1974. New species of freshwater nematodes - commensals of baikalian sponges. Zoologicheskii Zhurnal 53: 1081-1085. [In Russian].

Tsalolikhin S.Ya. 1975. New species from Lake Baikal abyssal zone. Zoologicheskii Zhurnal 54: 771775. [In Russian].

Zullini A. 2006. Order Triplonchida. In: Eyualem-Abebe, Transpurger W., Andrássy J. (eds.) Freshwater Nematodes: Ecology and Taxonomy: 293-325. CABI Publishing, Wallingford, UK.

Manuscript received: 26 June 2019

Manuscript accepted: 26 September 2019

Published on: 21 November 2019

Topic editor: Rudy Jocqué

Desk editor: Pepe Fernández

Printed versions of all papers are also deposited in the libraries of the institutes that are members of the EJT consortium: Muséum national d'histoire naturelle, Paris, France; Meise Botanic Garden, Belgium; Royal Museum for Central Africa, Tervuren, Belgium; Royal Belgian Institute of Natural Sciences, Brussels, Belgium; Natural History Museum of Denmark, Copenhagen, Denmark; Naturalis Biodiversity Center, Leiden, the Netherlands; Museo Nacional de Ciencias Naturales-CSIC, Madrid, Spain; Real Jardín Botánico de Madrid CSIC, Spain; Zoological Research Museum Alexander Koenig, Bonn, Germany; National Museum, Prague, Czech Republic. 